\title{
Evaluasi Kinerja Pelayanan Terpadu Satu Pintu pada dinas Penanaman Modal dan Pelayanan Perizinan di Kabupaten Dairi
}

\section{Performance Evaluation of the One Stop Integrated Services at the Investment and Licensing Services office in Dairi Regency}

\author{
Hetty Malina Sitorus ${ }^{1 *}$, Warjio ${ }^{2}$ \& Isnaini $^{3}$
}

1) Pasca Sarjana Magister Ilmu Administrasi Publik Universitas Medan Area, Indonesia

2) Departemen Ilmu Politik, Fakultas Ilmu Sosial dan Ilmu Politik,

Universitas Sumatera Utara, Indonesia

3) Fakultas Hukum, Universitas Medan Area, Indonesia

\section{Abstrak}

Penelitian ini bertujuan untuk mengevaluasi kinerja Dinas Penanaman Modal dan Pelayanan Perizinan Terpadu Satu Pintu Kabupaten Dairi sebagai penyelenggara PTSP. Kinerja Pelayanan dilihat dari dimensi Produktivitas, Kualitas Pelayanan, Responsivitas, Responsibilitas dan Akuntabilitas. Peneliti berupaya menggali informasi faktorfaktor yang mempengaruhi yang mempengaruhi kinerja organisasi yaitu dimensi dukungan organisasi, kemampuan manajemen dan kompetensi aparatur. Penelitian dilakukan dengan menggunakan metode deskriptif dengan pendekatan kualitatif yaitu mendeskripsikan fakta yang diperoleh melalui pengamatan, wawancara mendalam dan telaah dokumen. Kesimpulan penelitian menunjukkan bahwa kinerja DPMPPTSP Kabupaten Dairi secara umum masih belum optimal, namun pada dimensi responsivitas dan akuntabilitas telah menunjukkan hasil yang lebih baik. Kemampuan manajemen dan dukungan organisasi belum memadai, sedangkan kompetensi aparatur cukup baik. Komitmen kepala daerah bersama jajarannya sangat dibutuhkan untuk meningkatkan sarana dan prasarana pelayanan terutama pembangunan sarana parkir kenderaan pada Dinas DPMPPTSP Kabupaten Dairi, meningkatkan iklim investasi daerah, serta kebijakan insentif bagi aparatur secara proporsional.

Kata Kunci: Evaluasi, Kinerja, Pelayanan Terpadu Satu Pintu

\begin{abstract}
This study aims to evaluate the performance of the One-Stop Integrated Investment and Licensing Services Office of Dairi Regency as PTSP organizer. Service Performance can be seen from the dimensions of Productivity, Service Quality, Responsiveness, Responsibility and Accountability. Researchers sought to explore information on the influencing factors that affect organizational performance, namely the dimensions of organizational support, management ability and competence of the apparatus. The study was conducted using a descriptive method with a qualitative approach that is describing the facts obtained through observation, in-depth interviews and document review. The conclusion of the research shows that the performance of Dairi Regency DPMPPTSP in general is still not optimal, but on the dimensions of responsiveness and accountability have shown better results. Management capacity and organizational support are inadequate, while the competence of the apparatus is quite good. Commitment of regional heads together with their staff is needed to improve service facilities and infrastructure, especially the construction of vehicle parking facilities at the DPMPPTSP Office of Dairi Regency, to improve the regional investment climate, as well as the incentive policy for apparatus proportionally.
\end{abstract}

Keywords: Evaluation, Performance, One Stop Integrated Services

How to Cite: Hetty Malina Sitorus, Warjio \& Isnaini (2020). Evaluasi Kinerja Pelayanan Terpadu Satu Pintu pada dinas Penanaman Modal dan Pelayanan Perizinan di Kabupaten Dairi. Strukturasi: Jurnal Ilmiah Magister Administrasi Publik, 2(1): 98-106

*E-mail: hettymalina@gmail.com

ISSN 2550-1305 (Online)

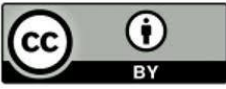




\section{PENDAHULUAN}

Penyelenggaraan PTSP di Kabupaten Dairi telah dirintis sejak tahun 2012 dengan Peraturan Daerah Kabupaten Dairi Nomor 3 Tahun 2012 tentang Organisasi dan tata Kerja Kantor Pelayanan Perizinan Terpadu, selanjutnya pada tahun 2016 dilebur dengan Peraturan Daerah Kabupaten Dairi Nomor 07 Tahun 2016 menjadi Dinas Penanaman Modal dan Pelayanan Perizinan Terpadu Satu Pintu(DPMPPTSP), Dasar pelaksanaan kewenangan Kepala DPMPPTSP Kabupaten Dairi dalam penyelenggaraan pelayanan perizinan dan non perizinan diatur melalui Peraturan Bupati Dairi dapat dilihat pada Tabel 1

Tabel. 1.1.

Kewenangan Kepala DPMPPTSP dalam Bidang Perizinan dan Non Perizinan

\begin{tabular}{|l|l|l|l|l|}
\hline No & Bidang Perizinan & $\begin{array}{l}\text { Perbub Nomor 12 } \\
\text { Tahun 2013 }\end{array}$ & $\begin{array}{l}\text { Perbub Nomor 4 } \\
\text { Tahun 2017 }\end{array}$ & $\begin{array}{l}\text { Perbub Nomor 8 } \\
\text { Tahun 2018 }\end{array}$ \\
\hline $\mathbf{1}$ & Perizinan Usaha & 39 & 40 & 38 \\
\hline $\mathbf{2}$ & Perizinan Tertentu & $\mathbf{1 1}$ & $\mathbf{2 2}$ & 64 \\
\hline 3 & Penanaman Modal & $\mathbf{1 2}$ & 8 & $\mathbf{2}$ \\
\hline 4 & Data dan Informasi & $\mathbf{1 0}$ & 9 & 9 \\
\hline
\end{tabular}

Sumber : Diolah dari data DPMPPTSP Kabupaten Dairi Tahun 2018.

Pendelegasian kewenangan di bidang pelayanan perizinan dan non perizinan tersebut meliputi pemprosesan, penandatangan dan pencabutan izin. Perubahan terhadap Peraturan Bupati Dairi tersebut beberapa kali dilakukan untuk merespon dinamika perkembangan kebutuhan masyarakat dan untuk menyesuaikan terhadap pemberlakuan Undang-undang Nomor 23 Tahun 2014 tentang Pemerintahan Daerah.

Realisasi penyelenggaraan PTSP dalam kurun waktu 2014 - 2017berdasarkan jenis perizinan dapat dilihat pada table 2 .

Tabel 2

Rekapitulasi Penerbitan Izin Pada DPMPPTSP Kabupaten Dairi Tahun 2014- 2017

\begin{tabular}{llllll}
\hline \multirow{2}{*}{ No } & JENIS IZIN & \multicolumn{4}{c}{ TAHUN } \\
\cline { 3 - 6 } & & $\mathbf{2 0 1 4}$ & $\mathbf{2 0 1 5}$ & $\mathbf{2 0 1 6}$ & $\mathbf{2 0 1 7}$ \\
\hline $\mathbf{1}$ & Bidang Penanaman Modal & $\mathrm{O}$ & $\mathrm{O}$ & 5 & $\mathbf{1}$ \\
$\mathbf{2}$ & Bidang Perizinan Tertentu & $\mathbf{1 2 0}$ & $\mathbf{1 4 4}$ & $\mathbf{1 1 5}$ & 99 \\
3 & Bidang Perizinan Usaha & 529 & 573 & 683 & 411 \\
\hline Jumlah & 649 & 717 & 803 & 511 \\
\hline
\end{tabular}

Sumber : Diolah dari data DPMPPTSP Kabupaten Dairi

Realisasi penerbitan perizinan selama ini diindikasikan tidak berbanding lurus dengan kinerja penyelenggaraan PTSP. Hal yang dapat menggambarkan kondisi tersebut antara lain sebagai berikut: 1) Ijin yang diterbitkan; 2) Capaian nilai survey Indeks Kepuasan Masyarakat; 3) Tim teknis belum bekerja secara optimal.

Dukungan Tim Teknis masih rendah dalam merekomendasi penerbitan izin, hal ini terjadi karena Tim teknis masih melekat pada SKPD Teknis, yang artinya masih merupakan tugas tambahan sebagai Tim Teknis yang terdiri dari pejabat Satuan Kerja Perangkat Daerah terkait yang mempunyai kompetensi dan kemampuan sesuai dengan bidangnya yang ditetapkan dengan keputusan Bupati Dairi. Tim ini bertugas melakukan pemeriksaan teknis di lapangan dibawah koordinasi kepala DPMPPTSP dan memiliki kewenangan untuk mengambil keputusan dalam memberikan rekomendasi mengenai diterima atau ditolaknya suatu permohonan perizinan. 
Evaluasi kinerja penyelenggaraan PTSP merupakan salah satu alterlanatif proses pembelajaran untuk melihat sejauh mana keberhasilan dan kekurangan pelaksanaan tugas selama ini, sekaligus dapat dijadikan dasar upaya perbaikan dalam rangka peningkatan kualitas pelayanan dimasa mendatang. Hakekatnya kewajiban setiap penyelenggara pelayanan publik untuk melakukan evaluasi kinerja secara periodic dengan indicator yang jelas dan terukur telah diatur dalam Undang - Undang Nomor 25 Tahun 2009 tentang Pelayanan Publik (Andika \& Tarigan, 2013; Nasution \& Sinaga, 2014; Simbolon \& Sembiring, 2015; Siregar, Kusmanto \& Isnaini. 2016).

\section{METODE PENELITIAN}

Penelitian ini dilaksankanakan di DPMPPTSP Kabupaten Dairi, penelitian ini bertujuan untuk melakukan evaluasi terhadap penyelenggaraan PTSP pada DPMPPTSP Kabupaten Dairi, menggunakan metode deskriptif dengan pendekatan kualitatif yang mencoba untuk melihat fenomena sosial yang terjadi saat ini dalam hubungannya kinerja penyelenggaraan PTSP, Istilah deskriptif diartikan upaya memberikan gambaran prosese penyelenggaraan PTSP Kabupaten Dairi.

Sumber data dalam penelitian kualitatif ini dari internal Dinas Penanaman Modal dan Pelayanan Perizinan Terpadu Satu Pintu Kabupaten Dairi, dan para pihak yang terkait dengan penyelenggaraan pelayanan sebagai data utama yang dilakukan melalui observasi dan wawancara terstruktur, adapun untuk melengkapi kebutuhan data dilakukan pengumpulan data pendukung melalui studi dokumentasi dari berbagai sumber. Meleong (2013) menjelaskan bahwa sumber daya penelitian kualitatif adalah tindakan, pernyataan lisan dan tertulis yang perlu dicermati serta benda lain dan dokumentasi yang perlu diamati sehingga diperoleh makna atas keberadaan tersebut.

Pada penelitian kualitatif, beberapa ahli menempatkan peneliti sekaligus sebagai instrument penelitian. Pada Penelitian ini peneliti bertindak selaku yang merencanakan penelitian, melakukan pengumpulan data, menganalisa data dan menyususn laporan penelitian. Peneliti telah merumuskan pedoman wawancara dan check list pengumpulan data sebagai alat bantu instrument penelitian.

Klasifikasi observasi menurut Sanafiah Faisal (dalam Sugiyono, 2013) adalah observasi berpartisipasi, observasi yang secara terang-terangan dan tersamar dan observasi yang tidak terstruktur. Pada penelitian kualitatif ini, penulis memilih observasi yang tidak terstruktur dimana tidak menggunakan pedoman khusus dan focus observasi dapat berkembang sesuai dengan perjalanan observasi.

Hakekatnya dalam wawancara terjadi pertukaran informasi antara dua pihak melalui Tanya jawab untuk mengetahui secara lebih mendalam terkait topic tertentu yang tidak dapat ditemukan melalui observasi. Klafisikasi wawancara menurut Esterberg (dalam Sugiono,2013) yaitu wawancara terstruktur, semi struktur dan tidak struktur. Pada penelitian ini, penulis menulis wawancara terstuktur mengacu kepada pedoman wawancara yang telah di buat dengan menggunakan alat rekam suara sebagai alat bantu., wawancara dilaksanakan kepada : a) Kepala DPMPPTSP Kabupaten Dairi; b) Kabid Perizinan pada DPMPPTSP Kabupaten Dairi; c) Kabid Pelayanan, Informasi 
dan Penanganan pengaduan pada DPMPPTSP Kabupaten Dairi; d) Sekretaris DPMPPTSP Kabupaten Dairi; e) Pengguna Layanan; f) Tim Teknis

Dokumentasi dan bentuk catatan data, laporan, peraturan, bahkan dalam bentuk gambar dan visual lainnya yang berkaitan dengan penyelenggaraan PTSP untuk mendukung hasil pengumpulan data melalui observasi dan wawancara. Peneliti menetapkan cheek list pengumpulan data untuk alat bantu dalam studi doumentasi.

Analisis data dilakukan secara bertahap sejalan dengan berlangsungnya pengumpulan data, penafsiran data dan tidak digeneralisasi berdasarkan kesamaan namun penafsiran diarahkan untuk menemukan hal mendasar sesuai kenyataan. Peneliti melakukan teknik triangulasi dengan memeriksa berbagai sumber daya yang lain untuk menemukan informasi yang di nilai menggambarkan kenyataan yang sesungguhnya pada penelenggaraan PTSP.

\section{HASIL DAN PEMBAHASAN}

Evaluasi Kinerja Pelayanan

Hasil studi dokumentasi menunjukkan bahwa realisasi penerbitan izin mulai tahun 2014 - 2017 sebanyak 2.680 dengan rincian berdasarkan jenis izin sebagaimana Tabel 4.

Tabel 4.

Volume Penerbitan Izin DPMPPTSP Kabupaten Dairi Tahun 2014 - 2017

\begin{tabular}{|l|l|l|l|l|l|}
\hline No & Jenis Izin & \multicolumn{2}{l}{ Tahun } \\
\cline { 3 - 6 } & & 2014 & 2015 & 2016 & 2017 \\
\hline 1 & Bidang Perizinan Usaha & & & & \\
\hline & a. Tanda Daftar Perusahaan (TDP) & 270 & 295 & 320 & 189 \\
\hline & b.Surat Izin Usaaha Perdagangan & 190 & 188 & 220 & 125 \\
\hline & c.Izin Usaha Industri & 6 & 4 & 14 & 1 \\
\hline & d.IIzin Lingkungan & 4 & 14 & 11 & 8 \\
\hline & e. Izin Usaha Jasa Konstruksi & 47 & 37 & 78 & 52 \\
\hline & f.Izin Reklame & 6 & 31 & 32 & 31 \\
\hline & g.Tanda Daftar Usaha Perjalanan Wisata (Biro Perjalanan Wisata) & 1 & 0 & 0 & 0 \\
\hline & $\begin{array}{l}\text { h. Izin Penyelenggaraan Angkutan Orang dalam trayek Perdesaan } \\
\text { dan Perkotaan }\end{array}$ & 0 & 0 & 0 & 1 \\
\hline & i. Izin usaha mobil angkutan orang & & & \\
\hline & j.Izin usaha mobil angkutan barang & 0 & 0 & 4 & 1 \\
\hline & kTanda Daftar usaha jasa makanan dan minuman, Jasa Boga & 4 & 3 & 1 & 1 \\
\hline 2 & Bidang Perizinan Tertentu & 0 & 1 & 2 & 1 \\
\hline & a,Izin Gangguan pemanfaatan Tanah & & & & \\
\hline & b.Izin Mendirikan Bangunan & 1 & 1 & 0 & 1 \\
\hline & c.Izin Pendirian Pendidikan PAUD & 70 & 65 & 75 & 64 \\
\hline & d.Izin Pendirian TK & 27 & 66 & 36 & 34 \\
\hline & e.Izin Pendirian SD & 4 & 7 & 0 & 0 \\
\hline & f.Izin Pendirian SMP & 4 & 1 & 0 & 0 \\
\hline & g.Izin Pendirian SMA & 2 & 1 & 1 & 0 \\
\hline & h.Izin Lembaga Pelatihan Kerja & 1 & 0 & 0 & 0 \\
\hline & i.Izin Lembaga Kursus & 3 & 2 & 1 & 0 \\
\hline & j.izin Tempat Berjualan Minuman Beralkohol & 8 & 1 & 2 & 0 \\
\hline 3 & Bidang Penanaman Modal & 1 & 0 & 1 & 1 \\
\hline & a.Izin Prinsip & & & & \\
\hline & b.Tanda daftar Industri & 0 & 0 & 0 & 1 \\
\hline & & 0 & 0 & 5 & 0 \\
\hline
\end{tabular}

Sumber : Di olah peneliti dari data DPMPPTSP Kabupaten Dairi 2018 
Pada Tabel 4, dapat dilihat bahwa terdapat peningkatan volume penerbitan izin tahun 2014, 2015 dan 2016, namun hal sebaliknya terjadi pada tahun 2017 yaitu adanya penurunan volume penerbitan izin. Kondisi ini dikarenakan pada tahun 2017 jumlah masyarakat yang mengajukan permohonan izin lebih sedikit dari pada tahun 2016.

Kinerja pelayanan dalam penelitian ini diartikan sebagai hasil capaian atau prestasi kerja PTSP pada kurun waktu tertentu, untuk mencapai tujuan dan sasaran yang telah ditetapkan sebagai wujud nyata dari akuntabilitas publik. Evaluasi kinerja pelayanan merupakan proses penilaian pelaksanaan tugas seseorang atau sekelompok orang atau unit-unit di DPMPPTSP sebagai penyelenggara pelayanan pada PTSP dan memberikan saran perbaikan untuk peningkatan kualitas pelayanan publik pada masa mendatang.

\section{Kontrubusi Retribusi Perizinan terhadap PAD.}

Hasil kontribusi penerimaan retribusi dihitung berdasarkan persentase penerimaan retribusi terhadap realisasi PAD pada tahun berjalan, berdasarkan studi dokumen hasilnya dapat di lihat pada table 4.4 .

Tabel 4.4.

Kontribusi Retribusi Perizinan terhadap PAD Kabupaten Dairi Tahun 2014 - 2017

\begin{tabular}{lllll}
\hline NO & Tahun & Target Retribusi Perizinan (Rp). & Realisasi PAD (Rp) & $\%$ \\
\hline 1 & 2014 & 300.00o.ooo.- & $216.854 .682 . .^{-}$ & 98, \\
2 & 2015 & 395.00o.ooo.- & $434.194 .885 .^{-}$ & 109,95 \\
3 & 2016 & $270.000 .000 .-$ & $278.758 .200 .-$ & 102 \\
4 & 2017 & $263.000 .000 .-$ & $277.526 .349 .50 .-$ & 105 \\
\multicolumn{5}{c}{ Sumber : Di olah peneliti dari data DPMPPTSP Kabupaten Dairi }
\end{tabular}

Kinerja pada dimensi produktivitas secara umum menunjukan hasil belum optimal berdasarkan hal sebagai berikut: Pertumbuhan volume penerbitan izin periode 2014 2016 telah menunjukan kenaikan, namun pada saat tahun 2017 mengalami penurunan; Kontribusi penerimaan retribusi terhadap PAD Kabupaten Dairi selama 2014 - 2017 hanya mencapai rata rata sebesar 0,35.

Kinerja pada dimensi kualitas pelayanan secara umum menunjukkan masih terdapat sebagian pengguna layanan yang belum merasakan kepuasan atas pelanggan yang diberikan, berdasarkan hal sebagai berikut: 1) Pengguna layanan belum merasakan kepuasan terhadap penerapan jangka waktu pelayanan, mekanisme dan prosedur pelayanan dibandingkan ketentuan yang telah ditetapkan pada Standar Pelayanan; 2) Pengguna layanan telah merasakan kepuasan terhadap kesesuaian antara penerapan persyaratan, biaya pelayanan, penanganan pengaduan dengan ketentuan yang telah ditetapkan pada Standar Pelayanan.

Kinerja pada dimensi responsivitas menunjukkan hasil yang baik, di mana penyelenggaraan pelayanan telah memberikan kemudahan dan kejelasan informasi pelayanan, keramahan petugas dalam membantu pengguna layanan, tersedianya sarana pengaduan, saran dan keluhan.

Kinerja pada dimensi responsibilitas secara umum menunjukkan hasil belum cukup baik berdasarkan hal sebagai berikut: 1) Penerapan jangka waktu pelayanan, mekanisme dan prosedur pelayanan masih belum sesuai dengan ketentuan Standar Pelayanan dan PTSP belum dapat diretapkan secara penuh satu pintu; 2) Biaya pelayanan untuk jenis pelayanan tertentu masih di nilai belum wajar, namun secara 
umum penerapan persyaratan dan biaya pelayanan telah mengacu kepada Standar Pelayanan.

Kinerja pada akuntabilitas menunjukkan hasil yang baik, di mana penyelenggara telah memiliki sistem informasi pelayanan yang dapat di akses dengan mudah dan telah menyampaikan laporan perkembangan kegiatan.

\section{Faktor-faktor yang Mempengaruhi Kinerja}

Pengaruh dukungan organisasi terhadap kinerja PTSP Kabupaten Dairi di lihat dari struktur organisasi, kejelasan mekanisme dan pembangian kerja, ketersediaan teknologi, sarana dan prasarana. Hasil penelitian dan pembahasan menunjukkan bahwa dukungan organisasi belum optimal terhadap kinerja PTSP berdasarkan hal sebagai berikut: 1) Pola PTSP belum dapat sepenuhnya diterapkan karena kontradiksi regulasi, berdasarkan Peraturan daerah Kabupaten Dairi tentang Pmbentukan Perangkat Daerah Kabupaten Dairi, pada struktur organisasi DPMPPTSP terdapat unsur Tim Teknis yang kedudukannya berada dalam suatu jenajng hirarkhi yang memiliki pertanggungjawaban sesuai garis komando. Berdasarkan Peraturan Bupati Dairi Nomor 20 Tahun 2016 tentang Kedudukan, Susunan Organisasi, Tugas dan Fungsi serta Tata Kerja Perangkat Daerah Kabupaten Dairi disebutkan bahwa kedudukan Tim Teknis tidak melekat pada DPMPPTSP Kabupaten Dairi. 2) Rendahnya komitmen pimpinan daerah dalam upaya melengkapi fasilitas sarana prasarana khususnya pembangunan tempat parkir kantor DPMPPTSP Kabupaten Dairi.

Pengaruh kemampuan manajemen terhadap kinerja PTSP Kabupaten Dairi di lihat dari kepemimpinan efektif dan koordinasi. Hasil Penelitian dan pembahasan menunjukkan bahwa kemampuan manajemen di nilai cukup memberikan pengaruh terhadap kinerja PTSP berdasarkan hal sebagai berikut: 1) Pola penyelenggaraan pelayanan DPMPPTSP kabupaten Dairi telah mencerminkan penerapan kepemimpinan efektif yang dapat di lihat melalui aspek Meaning, Membership dan Mastery; 2) Kendala dalam koordinasi DPMPPTSP Kabupaten Dairi dengan Tim Teknis, terutama pada pelaksanaan kegiatan peninjauan lapangan

Pengaruh kompetensi aparatur terhadap kinerja PTSP kabupaten dairi di lihat dari kemampuan dan keterampilan teknis, motivasi dan etos kerja. Hasil penelitian dan pembahasan menunjukkan bahwa kompetensi aparatur di nilai baik dalam menentukan kinerja PTSP berdasarkan hal sebagai berikut: 1) DPMPPTSP Kabupaten Dairi telah mengikuti pendidikan teknis secara berkala; 2) Motivasi dan etos kerja di bangun budaya kerja organisasi dan secara formal diperkuat dengan penerapan Kode Etik.

\section{SIMPULAN}

Berdasarkan hasil pembahasan dan analisis data penelitian, maka kepada DPMPPTSP Kabupaten Dairi sebagai penyelenggara PTSP disarankan untuk melaksanakan beberapa aktivitas dalam rangka meningkatkan kinerja pelayanan dan memeprkuat faktor-faktor penentu kinerja organisasi: 1) Evaluasi Kinerja Pelayanan yang terdiri dari: a. Produktivitas: 1) Melaksanakan identifikasi dan pendataan wajib retribusi perizinan Kabupaten Dairi; 2) Menyampaikan ususlan pemberian insentif 
retribusi/upah pungut bagi penyelenggara PTSP Kabupaten Dairi. (b). Kualitas Pelayanan dan Responsibilitas: 1) Melakukan harmonisasi dan merevisi ketentuan Standar Pelayanan mengacu perundang undangan yang terbaru; 2) Mengembangkan pola Pelayanan Secara Elektronik melalui penerapan sistem aplikasi sehingga pelayanan dapat diberikan secara on line sehingga proses kerja dapat lebih cepat dan berlngsung.

Faktor-faktor yang mempengaruhi kinerja: Dukungan Organisasi: 1) Menyampaiakan usulan perubahan Peraturan Bupati Dairi Nomor 20 Tahun 2016 tentang Kedudukan, Susunan Organisasi, Tugas dan Fungsi serta Tata Kerja Perangkat Daerah Kabupaten Dairi, untuk mempertegas kedudukan Tim Teknis yang secara formal merupakan bagian dari struktur organisasi namun dalam kedudukannya tidak melekat pada DPMPPTSP Kabupaten Dairi. 2) Kemampuan Manajemen: a) Merumuskan mekanisme kerja dengan merujuk kepada Peraturan Presiden Nomor 97 Tahun 2014 yang menetapkan jangka waktu pelayanan paling lama 7 hari; b) mengusulkan kepada Bupati Dairi agar untur Tim Teknis dapat penugasan secara penuh di DPMPPTSP kabupaten Dairi.

\section{DAFTAR PUSTAKA}

Aluguro, K.S. (2002). Analisis Pengaruh Iklim Kerja Terhadap Kepuasan Kerja Pegawai di Sekretariat Daerah Kota Semarang. Tesis. Program Studi Magister Manajemen Universitas Diponegoro Semarang.

Andika, M, dan Tarigan, U. (2013). Evaluasi Kinerja Pemerintah Desa Bandar Tengah Kecamatan Bandar Khalifah Kabupaten Serdang Bedagai, JPPUMA: Jurnal Ilmu Pemerintahan dan Sosial Politik UMA (Journal of Governance and Political UMA), 1 (2): 98-111.

Arikunto, S. (2006). Prosedur Penelitian Suatu Pendekatan Prakti. Jakarta: Bina Aksara.

Armanu, T. (2005). "Hubungan Kepemimpinan, Budaya, Strategi, dan Kinerja: Pendekatan Konsep". Jurnal Manajemen \& Kewirausahaan, Vol. 7, NO. 1.

Arpi, F. Susanna, T. Carolyn, M.B., Thomas, S. and Ho, P.H., (2013). I See Me the Way You See Me The Influence of Race on Interpersonal and Intrapersonal Leadership Perceptions: Journal of Leadership \& Organizational Studies, pg. 102-119.

Bernardin, H.J, (2003). Human Resources Management: An Experiential. Approach, 3rd edition. MCGRAWHill Shool Education group.

Bungin, B, (2010). Metodologi Penelitian Kuantitatif (Komunikasi, Ekonomi, dan Kebijakan Serta Ilmu-ilmu Sosial Lainnya). Jakarta: Kencana.

Dessler, G. (2007). Manajemen Sumber Daya Manusia, buku 1 \& 2. Jakarta : Penerbit Indeks.

G, Shuck Brad, Reio Jr Thomas. (2013). Employee Engagement and Well-Being: A Moderation Model and Implications for Practice: Journal of Leadership \& Organizational Studies, pg. 43-58.

Gentry William A, Eckert Regina H, Munusamy Vijayan P, Stawiski Sarah A. \& Martin Jacob L. (2013). The Needs of Participants in Leadership Development Programs A Qualitative and Quantitative CrossCountry Investigation: Journal of Leadership \& Organizational Studies, pg. 83-101.

Ghozali, I. (2001). Aplikasi Analisis Multivariate Dengan Program SPSS. Semarang: Penerbit Undip.

Gustina, A. \& Kusbramayanti. (2000). "Leadership and Organizational Culture Relationship Analysis on Job Performance and Satisfaction Using SEM at PT. Carita Boat Indonesia bahwa kepemimpinan dan budaya organisasi bersama-sama mempunyai pengaruh yang positif terhadap kinerja karyawan. Penelitian ini di lakukan dengan 100 orang karyawan sebagai responden: Jurnal. Universitas Trisakti.

Handoko,T.H, (2001). Manajemen Personalia Dan Sumber Daya Manusia. Yogyakarta: Badan Penerbit Fakultas Ekonomi.

Hariska, R, (2008). Hubungan Iklim Kerja Dengan Kepuasan Kerja Pegawai di Balai Besar Keramik. Bandung: Fakultas Ilmu Pendidikan Universitas Pendidikan Indonesia.

Hasibuan, M. (2003). Organisasi dan Motivasi. Jakarta: PT. Bumi Aksara.

Hasibuan. M.S.P. (2001). Manajemen Sumber Daya Manusia, Jakarta : PT. Bumi Aksara. 
Hasintongan, P. (2012). Pengaruh Kepemimpinan Terhadap Kinerja Pegawai Dalam Pelaksanaan Inventarisasi dan Penilaian Barang Milik Negara Pada Kantor Pelayanan Kekayaan Negara dan Lelang Medan: Tesis. Universitas Medan Area Medan.

Idrus, M. (2009). Metode Penelitian Sosial: Pendekatan Kualitatif dan Kuantitatif. Jakarta: Erlangga.

Kardi, A.B. Susanto \& Koesnadi. (2003). Quantum Leadership: Kepemimpinan dalam Dunia Bisnis \& Dunia Militer. Jakarta: Grasindo.

Kartono, K. (2004). Pemimpin Dan Kepemimpinan: Apakah Kepemimpinan Abnormal Itu. Jakarta: Rajawali Press.

Kopperud Hofslett Karoline, Martinsen Qyvind \& Humborstad Wong Sut I., (2013). Engaging Leaders in the Eyes of the Beholder On the Relationship Between Transformational Leadership, Work Engagement, Service Climate, and Self-Other Agreement: Journal of Leadership \& Organizational Studies, pg. 29-42.

Kreitner \& Kinicki, (2005). Perilaku Organisasi. Jakarta: Salemba empat.

Mangkunegara, AA. A.P. (2013). Manajemen Sumber Daya Manusia Perusahaan. Bandung: Remaja Rosdakarya.

Mangkunegara, P. (2002). Manajemen Sumber Daya Manusia Perusahaan. Bandung: PT. Remaja Rosdakarya.

Mangkunegara. (2006). Evaluasi Kinerja Sumber Daya Manusia. Bandung: PT. Refika Aditama.

Mondy, R.W. (2008). Manajemen Sumber Daya Manusia, Buku 1 \& 2. Jakarta : Penerbit Erlangga.

Mulyanto. (2010). Pengaruh Kepemimpinan dan Motivasi Kerja Terhadap Kinerja Organisasi Dengan Kepuasan Kerja Sebagai Variabel moderating (Studi Kasus di Dinas Pertanian Tanaman Pangan, Perkebunan dan Kehutanan Kabupaten Karanganyar): Skripsi.

Nafisah, S.T.R. \& Durrotun. (2006). Analisis Pengaruh Gaya Kepemimpinan Terhadap Kepuasan Kerja, Komitmen Organisasi Dan Kinerja Karyawan (Studi Empiris Pada Departemen Agama Kabupaten Kendal dan Departemen Agama Kota Semarang): Jurnal studi manajemen \& organisasi. Vol 3, No. 2, Juli, tahun 2006.

Nasution, F.R. dan Rudi S.S., (2014). Evaluasi Kinerja Pegawai Kantor Samsat dalam Pelayanan Bea Balik Nama Kendaraan Bermotor, JPPUMA: Jurnal Ilmu Pemerintahan dan Sosial Politik UMA (Journal of Governance and Political UMA), 2 (1): 1-17.

Puapowarsito, A.H. (2008). Metode Penelitian Organisasi Dengan Aplikasi Program SPSS. Bandung: Humaniora.

Rivai. (2004). Manajemen Sumber Daya Manusia Untuk Perusahaan: Dari Teori Ke Praktik. Jakarta: PT. Raja Grafindo.

Robbins \& Judge. (2007). Organizational Behavior Twelfth Edition. Jakarta: Prenhallindo.

Robbins, S. (2003). Perilaku Organisasi. Jakarta: Penerbit Gramedia.

Santoso. (2002). Buku Latihan SPSS Statistik Parametrik. Jakarta: PT. Elex Media Komputindo.

Sedarmayanti. (2008). Sumber Daya Manusia dan Produktivitas Kerja. Jakarta: Mandar Maju.

Silok, P. (2012). "Pengaruh Kepemimpinan Terhadap Prestasi Kerja Pegawai Negeri Sipil Di Rumah Sakit Umum Kabanjahe Kabupaten Karo": Tesis. Universitas Medan Area Medan.

Simanjuntak, P.J. (2005). Manajemen dan Evaluasi Kinerja. Jakarta: FE UI.

Simbolon, A.H., dan Walid M.S., (2015). Evaluasi Kinerja Badan Permusyawaratan Desa dalam Penyelenggaraan Pemerintahan Desa, JPPUMA: Jurnal Ilmu Pemerintahan dan Sosial Politik UMA (Journal of Governance and Political UMA), 1 (1): 143-159.

Siregar, A.B., Kusmanto, H. Isnaini. (2016), Evaluasi Kinerja Kepala Sekolah Menengah Kejuruan SeKabupaten Langkat Tahun 2015, Jurnal Administrasi Publik, 6 (1): 13-19

Sjahruddin, Mariani Dian \& Machasin. (2012). Pengaruh Kepemimpinan Dan Pengawasan Terhadap Kedisiplinan Kerja Karyawan Pada PT. Perkebunan Nusantara V Kebun Inti Sei Galuh Kabupaten Kampar: Jurnal Penelitian.

Strom Diana L., Sears Karen L., \& Kelly Kristine M. (2013). Work Engagement The Roles of Organizational Justice and Leadership Style in Predicting Engagement Among Employees: Journal of Leadership \& Organizational Studies, pg. 71-82.

Sugiyono. (2008). Metode Penelitian Kuantitatif, Kualitatif dan R \& D. Bandung: Penerbit Alfabeta.

Sukarno, A. (2008). Berbagai Pendekatan Dalam Proses Belajar dan Mengajar. Jakarta: Kencana Persada Media.

Sulistiyani. (2004). Memahami Good Governance: Dalam Perspektif Sumber Daya Manusia. Jakarta: Gava Medi.

Sunyoto \& Burhanuddin. (2011). Perilaku Organisasi. Jakarta: CAPS.

Sutrisno, H. (2004). Metode Research, Vol.3. Yogyakarta: Penerbit Andi. 
Hetty Malina Sitorus, Warjio \& Isnaini. Evaluasi Kinerja Pelayanan Terpadu Satu Pintu pada dinas

Teman, H.K. (2005). Kesimpulan terhadap 7382 orang karyawan pabrik yang dipakai sebagai obyek penelitian bahwa budaya organisasi berpengaruh terhadap motivasi dan kepuasan kerja serta kinerja pada karyawan industri pengolahan kayu skala menengah di Jawa Timur. Jurnal Penelitian. Universitas Khatolik Widya Mandala Surabaya.

Wijaya. (2009). Analisis Data Penelitian Menggunakan SPSS. Yogyakarta: Kanisius.

Wursanto. (2009). Dasar-dasar Ilmu Organisasi. Yogyakarta: Kanisius.

Zainun, B. (1989). Manajemen dan Motivasi. Jakarta: Balai Aksara. 